\title{
Comparison of Chromatin Structure of Rat Mammary Glands between the Stages of Lactation and Regression after Weaning
}

\author{
Masaaki Hrrose, Masatoshi Maki*, Keiko AnABUKI, Kiyozo Hasegawa \\ and Hideo CHIBA*
}

Department of Food Science and Nutrition, Nara Women's University, Nara, Nara 630

*Department of Food Science and Technology, Kyoto University, Kyoto, Kyoto 606

Received May 17, 1979

\begin{abstract}
The chromatin structure of rat mammary glands was compared between two different developmental stages (5th day of lactation and 7th day of regression after weaning) when chromatin template activity for in vitro transcription declines more than twice. The DNA repeat length of the nucleosome was essentially unvariable between these stages (lactation, $195 \pm 7$; regression, $198 \pm 10$ nucleotide pairs). Gel electrophoresis of histones showed that histone H1 is more heterogeneous in regression than in lactation. The contents of the HMG proteins per DNA were much greater in the lactation than in the regression mammary gland.
\end{abstract}

The milk protein synthesis which takes place in the mammary glands during the lactation stage of mammals is controlled by the interaction of peptide and steroid hormones. Results from several laboratories have shown that the regulation of RNA synthesis, including rRNA $^{1,2)}$ and specific mRNA ${ }^{3 \sim 8)}$ coding for milk proteins, is closely related with the induction of the milk proteins. Our previous report ${ }^{9}$ ' has shown that chromatin template activity for in vitro transcription changes during pregnancy, lactation and regression of the rat mammary glands, and that it shows the highest levels at early lactation when intracellular levels of rRNA and mRNA are known to be at their maximum. It is very likely that the chromatin template plays, at least in part, an important role in the transcriptional regulation in the mammary glands.

Although knowledge of the fundamental structure of chromatin, called nucleosome, ${ }^{107}$ has been accumulated, the question concerning the correlation between transcriptional activity and the structure of chromatin remains to be solved. The chromatin template activity of the rat mammary glands declines about two fold during the stage from early lactation to regression after weaning. ${ }^{9)}$ To investigate transcriptional activity and the structure of chromatin, we have undertaken experiments to compare properties of mammary gland chromation with respect to these two different developmental stages.

This paper shows that the DNA repeat length of the nucleosome is essentially unvariable between these stages, and that quantitative and qualitative alteration in chromosomal proteins, particularly in the complements of the high mobility group (HMG) proteins, is probably involved in the change in the template activity of rat mammary gland chromatin.

\section{MATERIALS AND METHODS}

Reagents. Protease $\mathrm{K}$ and $\lambda \mathrm{dv}-1 \mathrm{DNA}$ were purchased from Boehringer Mannheim. Restriction endonuclease Hae III was purchased from Miles Biochemicals. Micrococcal nuclease and phenylmethylsulfonyl fluoride were obtained from Sigma.

Preparation of nuclei. Female Wister rats of 5th day of lactation or 7 th day of regression after weaning were decapitated, and the removed mammary glands were rinsed in cold saline and quickly frozen on dry ice, and then stored at $-80^{\circ} \mathrm{C}$. Calf thymus was obtained from a slaughterhouse, and stored in the same way. Nuclei were preapred essentially as described by Tsai 
et al. ${ }^{11)}$ except that all buffers contained $0.5 \mathrm{~mm}$ phenylmethylfonyl fluoride as a proteolytic inhibitor. The tissues $(20 \mathrm{~g})$ were homogenized in $80 \mathrm{ml}$ of Buffer A (50 mM Tris- $\mathrm{HCl}, \mathrm{pH} 7.5,25 \mathrm{mM} \mathrm{KCl,} 2 \mathrm{mM} \mathrm{MgCl}_{2}$, $0.5 \mathrm{~mm}$ phenylmethylsulfonyl fluoride) containing $0.5 \mathrm{M}$ sucrose by a homogenizer (Ultra Turrax, Type TP-18/2). $40 \mathrm{ml}$ of this buffer was added to the sample, then the solution was homogenized in the same way. The homogenate was filtered through four layers of gauze and centrifuged for $10 \mathrm{~min}$ at $1,200 \times \mathrm{g}$. The pellet was dispersed in $90 \mathrm{ml}$ of Buffer A containing $2.1 \mathrm{M}$ sucrose, and the solution was centrifuged for $60 \mathrm{~min}$ at $30,000 \times \mathrm{g}$ with a Beckman SW-25.1 rotor. The pellet was dispersed in Buffer B (50 mM Tris- $\mathrm{HCl}, \mathrm{pH} 7.5,2 \mathrm{~mm}$ $\mathrm{MgCl}_{2}, \quad 0.5 \mathrm{mM}$ phenylmethylsulfonyl fuoride, $50 \%$ glycerol) to give DNA concentration of about 1.0 $\mathrm{mg} / \mathrm{ml}$. The nuclear solution was stored at $-20^{\circ} \mathrm{C}$. The amount of DNA was determined by the diphenyIamine method. ${ }^{2}$ )

Nuclease digestion. The nuclear solution containing $0.18 \mathrm{mg}$ DNA was centrifuged and the pellet was dispersed in $0.7 \mathrm{ml}$ of Buffer $\mathrm{C}(25 \mathrm{~mm}$ Tris- $\mathrm{HCl}$, pH 7.7, 0.25 mM EDTA, 0.5 mM phenylmethylsulfonyl fluoride, $1 \mathrm{mM} \mathrm{CaCl}$ ). Nuclei were digested by micrococcal nuclease under the conditions described in the legend of Fig. 1. The sample was mixed with $35 \mu \mathrm{l}$ of $0.1 \mathrm{M}$ EDTA, pH $7.0,15 \mu \mathrm{l}$ of $10 \%$ sodium dodecyl sulfate and $35 \mu \mathrm{l}$ of $1 \mathrm{mg} / \mathrm{ml}$ of proteinase $\mathrm{K}$. After incubation for $2 \mathrm{hr}$ at $37^{\circ} \mathrm{C}$, the solution was mixed with $0.32 \mathrm{ml}$ of $3.5 \mathrm{M} \mathrm{NaClO}_{4}$ and $0.56 \mathrm{ml}$ of phenol. After $5 \mathrm{~min}-\mathrm{agitation}$, the sample was mixed with $0.56 \mathrm{ml}$ of chloroform/isoamylalcohol (24/1). The solution was centrifuged, then the upper layer was removed. DNA was precipitated with 2.5 volumes of ethanol at $-20^{\circ} \mathrm{C}$ overnight. Sizes of DNA were determined by using the restriction endonuclease Hae III digest of $\lambda \mathrm{dv}-1$ DNA, the sizes of which were determined by Steinmetz et $a .^{13}{ }^{3)} \quad \lambda \mathrm{dv}-1$ DNA $(0.12 \mathrm{mg} / \mathrm{ml})$ in $15 \mathrm{~mm}$ Tris- $\mathrm{HCl}$ buffer, pH 7.4 containing $15 \mathrm{mM} \mathrm{MgCl}_{2}$ and $0.001 \%$ mercaptoethanol was digested with 6 units of restriction endonuclease Hae III for $70 \mathrm{~min}$ at $37^{\circ} \mathrm{C}$. The reaction was terminated by the addition of sodium dodecyl sulfate solution. The DNA fragments were isolated by phenol extraction and subsequent ethanol precipitation.

Electrophoresis was carried out in $2.5 \%$ polyacrylamide $-0.5 \%$ agarose gels. The buffer system was that described by Peacock and Dingman. ${ }^{14}$ ) The gels were stained with $0.002 \%$ ethidium bromide for $30 \mathrm{~min}$, and the DNA bands were photographed through a red filter on illumination with ultraviolet light.

Histones. Histones were prepared by acid extraction from nuclei and subsequent precipitation in ethanol as described by Bonner et al. ${ }^{15)}$ Electrophoresis was carried out as described by Panyim and Chalkley. ${ }^{10}$ )
Gels contained $15 \%$ acrylamide $0.1 \%$ methylenebisacrylamide, and were run at $115 \mathrm{~V}$ for $21 \mathrm{hr}$ at $4^{\circ} \mathrm{C}$. Gels were stained with $0.25 \%$ Coomassie blue in $20 \%$ methanol- $7 \%$ acetic acid overnight, and destained in $20 \%$ methanol- $7 \%$ acetic acid.

High mobility group proteins. The high mobility group (HMG) proteins were prepared as described by Walker et $\left.a l .{ }^{17}\right)$ The nuclei ( $0.75 \mathrm{mg}$ of DNA) were homogenized in $1 \mathrm{ml}$ of $0.35 \mathrm{M} \mathrm{NaCl}$ containing $0.5 \mathrm{mM}$ phenylmethylsulfonyl fluoride, then the solution was centrifuged at $11,000 \times g$ for $15 \mathrm{~min}$. The pellet was stored at $-20^{\circ} \mathrm{C}$ until used for nonhistone protein preparation. The supernatant was made $0.2 \mathrm{~N}$ in $\mathrm{HCl}$, and the HMG proteins were precipitated by the addition of 6 volumes of acetone. The precipitate obtained by centrifugation at $1,200 \times g$ for $15 \mathrm{~min}$ was washed twice with acetone containing $0.014 \mathrm{~N}-\mathrm{HCl}$ and dried. The HMG proteins were dissolved in $0.01 \mathrm{~N}$ acetic acid containing $15 \%$ sucrose and $20 \%$ mercaptoethanol, and were incubated for $20 \mathrm{~min}$ at $60^{\circ} \mathrm{C}$. Electrophoresis was carried out according to the procedure of Johns. ${ }^{18)}$ Gels were run at $200 \mathrm{~V}$ for $4.5 \mathrm{hr}$ at $4^{\circ} \mathrm{C}$, then stained and destained as described for the electrophoresis of histones. Densitometric tracings were carried out with a Shimadzu densitometer CS-910.

Nonhistone chromosomal proteins. Nonhistone proteins which are not extracted from nuclei by $0.35 \mathrm{M}$ $\mathrm{NaCl}$ treatment were prepared according to the method of Wilson and Spelsberg. ${ }^{1 \theta}$ ) The residue of $0.35 \mathrm{M}$ $\mathrm{NaCl}$ extraction was suspended in $3.0 \mathrm{ml}$ of $0.4 \mathrm{~N}$ $\mathrm{H}_{2} \mathrm{SO}_{4}$ and histones were removed by centrifugation. The pellet was washed once with $3.0 \mathrm{ml}$ of $0.4 \mathrm{~N} \mathrm{H}_{2} \mathrm{SO}_{4}$. DNA-nonhistone protein complexes were dispersed in $2.0 \mathrm{ml}$ of Buffer $\mathrm{D}(0.1 \mathrm{M}$ Tris- $\mathrm{HCl}, \mathrm{pH} 7.5,2.0 \mathrm{~mm}$ $\mathrm{MgCl}_{2}$ and $2.0 \mathrm{mM} \mathrm{CaCl}$ ), and to the solution $50 \mu \mathrm{l}$ of $0.2 \mathrm{mg} / \mathrm{ml}$ of pancreatic DNase $I$ was added. After $30 \mathrm{~min}$ incubation at $30^{\circ} \mathrm{C}$, the reaction was terminated by the addition of $0.65 \mathrm{ml}$ of $1.25 \mathrm{~N}$ perchloric acid. Nonhistone proteins collected by centrifugation were dissolved in $0.2 \mathrm{ml}$ of $62.5 \mathrm{mM}$ Tris- $\mathrm{HCl}, \mathrm{pH} 6.7$ containing $1.0 \%$ sodium dodecyl sulfate, $25 \%$ glycerol and $0.02 \%$ mercaptoethanol. After the solution was incubated at $60^{\circ} \mathrm{C}$ for 20 min, it was mixed with $0.25 \mathrm{ml}$ of $0.05 \%$ bromophenol blue. Gel electrophoresis was performed with the system of Laemmli. ${ }^{20}$ Gels were fixed in 50\% ethanol-10\% acetic acid for $1 \mathrm{hr}$ and stained in $0.1 \%$ Coomassie blue $-50 \%$ acetic acid- $10 \%$ methanol overnight, and destained in $7 \%$ acetic acid.

\section{RESULTS}

\section{DNA Repeat length of nucleosome}

To see if the variation in the DNA repeat length of mammary gland chromatin is in- 


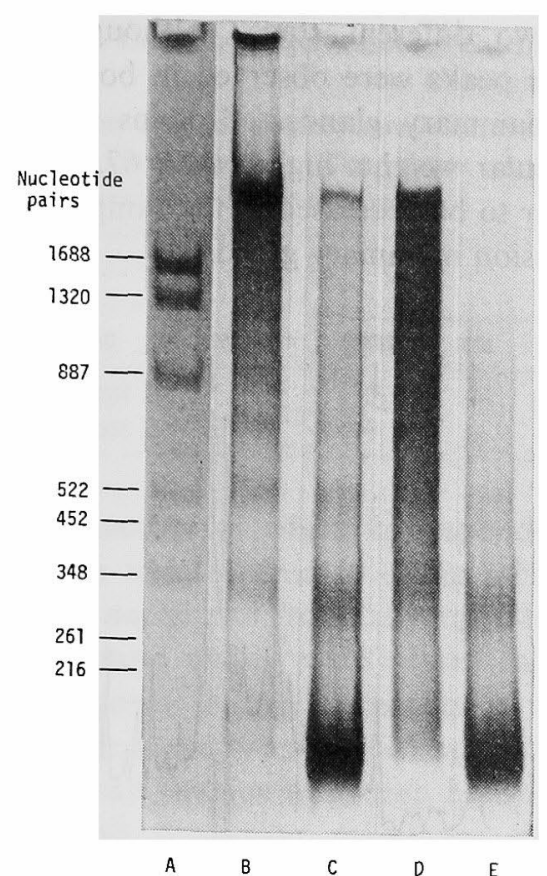

FIG. 1. Polyacrylamide-Agarose Gel Electrophoresis of Micrococcal Nuclease Digests of Mammary Gland Nuclei.

Nuclei $(0.26 \mathrm{mg} / \mathrm{ml} \mathrm{DNA})$ from the lactation (slots B and $\mathrm{C}$ ) or regression mammary glands (slots D and $\mathrm{E}$ ) were digested with $0.05 \mu$ molar units (slots B and D) or $0.25 \mu$ molar units (slots $\mathrm{C}$ and $\mathrm{E}$ ) of micrococcal nuclease for $7 \mathrm{~min}$ at $37^{\circ} \mathrm{C}$. The isolation of DNA and gel electrophoresis were carried out as described in Materials and Methods. The restriction fragments of $\lambda d v-1$ DNA were electrophoresed in slot A.

volved in the difference in the chromatin template activity for in vitro transcription, the mammary gland nuclei were digested by micrococcal nuclease, then the sizes of DNA fragments were compared between lactation and regression stages of rats. Figure 1 shows that the nuclease produced DNA fragments which migrated on polyacrylamide-agarose gels as multiples of a repeat length. To determine the DNA sizes, the logarithms of restriction fragment lengths were plotted against distance of migration. As shown in Fig. 2, the sizes of the DNA fragments were very similar between lactation and regression stages. By analysis of mild digestion experiments (Fig. 1B and D) the DNA repeat length was calculated to be $195 \pm 7$ nucleotide pairs for lactation and

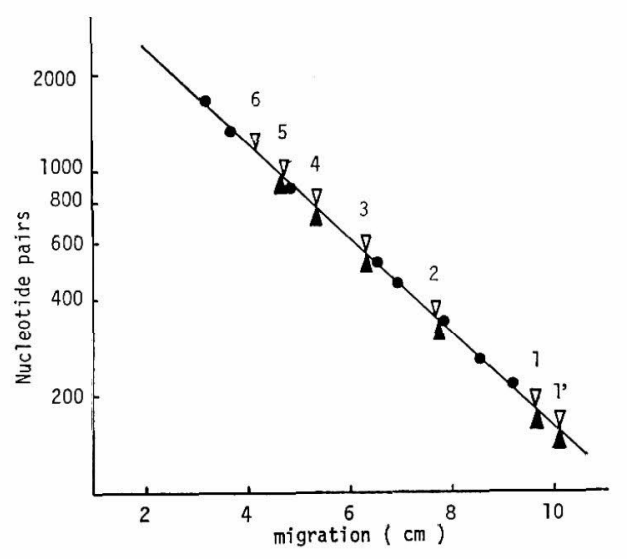

FIG. 2. Determination of the Sizes of DNA Fragments from Micrococcal Nuclease Digests.

The distance of migration of Hae III fragments (Fig. $1 \operatorname{slot}$ A) was plotted against logarithms of the number of nucleotide pairs (๑). With this plot, the sizes of multiple DNA bands (Nos. 1 6) from mild digestion of mammary gland nuclei (Fig. 1 slots B and $\mathrm{D}$ ) were determined. Only the monomer bands from the extensive digestion (Fig. 1 slots $\mathrm{C}$ and $\mathrm{E}$ ) were also plotted $\left(1^{\prime}\right) . \quad \nabla$, lactation; $\mathbf{\Lambda}$, regression.

$198 \pm 10$ nucleotide pairs for regression. These results indicate that the DNA repeat length of the fundamental nucleosome structure is essentially unvariable during the period from early lactation to regression of the mammary glands. In Fig. 2, the monomer DNA bands which were produced by extensive nuclease digestion (Fig. 1, C and E) were also plotted. The sizes of these DNA bands were 149 nucleotide pairs for lactation and 151 nucleotide pairs for regression mammary glands. These sizes were slightly larger than nucleosome core DNA (140 nucleotide pairs). ${ }^{10)}$ Probably linker DNA which is known to connect nucleosome cores was not able to be completely digested under the conditions which we employed.

\section{Histones}

Recent studies have shown that post translational modification of histones is correlated with transcriptional activity of chromatin. Histones isolated from the mammary gland nuclei were analyzed by acid-urea gel electrophoresis. As shown in Fig. 3, electrophoretic patterns of mammary gland histones were es- 


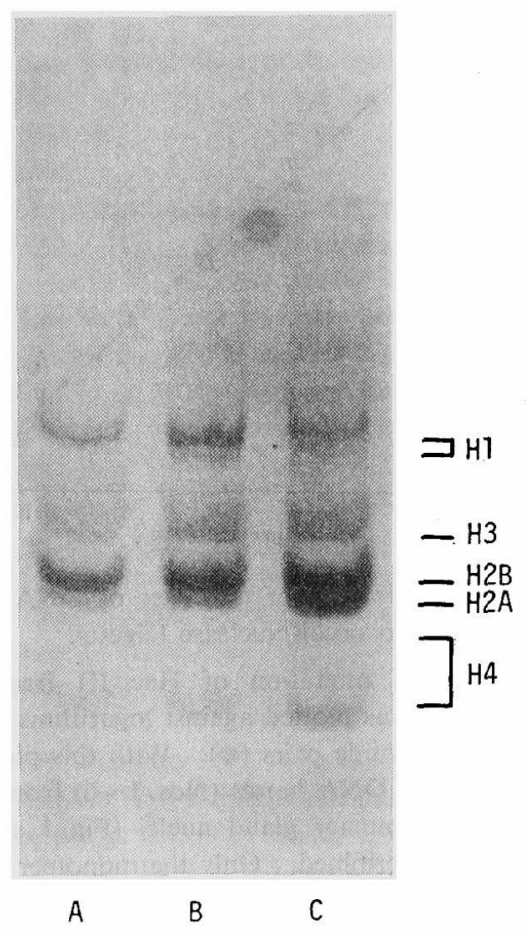

FIG. 3. Acid-Urea-Polyacrylamide Gel Electrophoresis of Histones.

Histones were isolated from lactation mammary glands (A), regression mammary glands (B) and calf thymus (C). Electrophoresis was carried out as described in Materials and Methods.

sentially identical with the well characterized calf thymus histones. No significant difference in the extent of acetylation of histone $\mathrm{H} 3$ and H4 was observed between lactation and regression stages of the mammary glands. A major difference between these stages was observed in histone $\mathrm{H} 1$. Histone $\mathrm{H} 1$ appeared to be more heterogeneous in regression than in lactation mammary glands.

\section{Nonhistone chromosomal proteins}

As we showed in an earlier report, ${ }^{9 !}$ the amount of nonhistone proteins per DNA is significantly variable during the mammary gland development. The gel electrophoretic patterns of nonhistone proteins which are not extractable by the $0.35 \mathrm{M} \mathrm{NaCl}$ treatment were compared between lactation and regression of the mammary glands. As shown in Fig. 4, the electrophoretic pattern was variable for the two different stages, although the two higher peaks were observed in both stages of the mammary glands. Proteins which have molecular weights higher than 67,000 daltons appear to be decreased in the sample from the regression mammary glands.

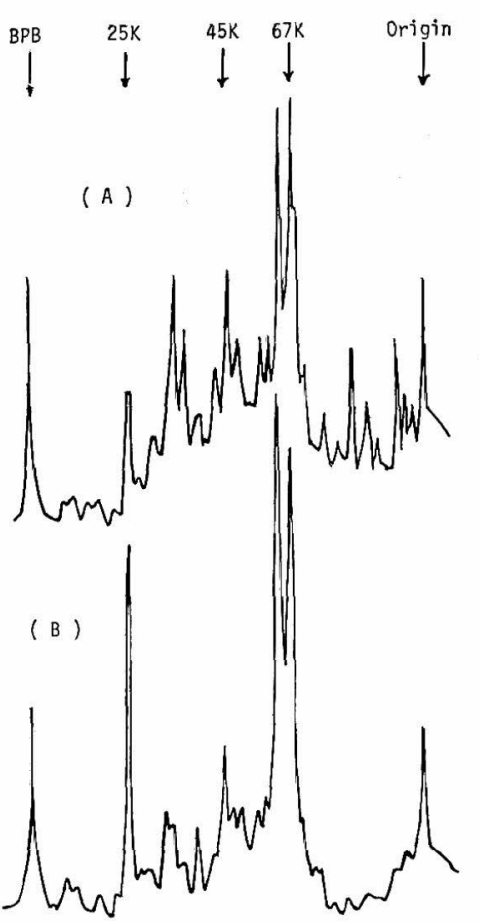

FIG. 4. Nonhistone Chromosomal Proteins of the Mammary Glands.

Nonhistone chromosomal proteins which were not extracted with $0.35 \mathrm{M} \mathrm{NaCl}$ treatment from mammary gland nuclei were isolated and electrophoresed as described in Materials and Methods. As molecular weight markers, bovine serum albumin $(67,000)$, ovalbumin $(45,000)$ and chymotrypsinogen A $(25,000)$ were used. (A), lactation; (B), regression.

\section{High mobility group proteins}

The HMG proteins, a group of nonhistone chromosomal proteins, have been shown to occur in several tissues and suggested to be implicated in transcriptionally active chromatin structure. To see if the HMG proteins are present in the rat mammary glands, proteins were isolated from the mammary gland nuclei under the conditions which enable the isolation of the HMG protein fraction, and were separated by acid gel electrophoresis. Pro- 
Table I. Comparison of Chromosomal Protein Contents between lactation and REgRession of the Mammary Glands

Isolation and gel electrophoresis of HMG proteins and histones were carried out as described in MATERIALS AND METHODS. The protein contents per nuclear DNA were determined from the area of each protein on tracing with a densitometer.

\begin{tabular}{lccccccc}
\hline & \multicolumn{7}{c}{$\begin{array}{c}\text { Ratio of protein contents per nuclear DNA } \\
\text { (Regression / Lactation) }\end{array}$} \\
\cline { 2 - 7 } & HMG-1 & HMG-2 & H1 & H2A + H2B & H3 & H4 \\
\hline Experiment 1 & 0.36 & 0.57 & 1.06 & 1.17 & 1.16 & 1.33 \\
Experiment 2 & 0.38 & 0.69 & 1.22 & 1.16 & 1.15 & 1.21 \\
\hline
\end{tabular}

teins, the quantity of which corresponded to the amounts isolated from $0.12 \mathrm{mg}$ DNA of calf thymus nuclei and from $0.24 \mathrm{mg}$ DNA of mammary gland nuclei, were placed in each well. As shown in Fig. 5, the peaks which have the same mobility as HMG-1 and HMG-2 proteins of calf thymus were seen both in the lactation and regression mammary glands. The complements of HMG proteins were much greater in lactation nuclei than in regression nuclei. The areas of the mammary HMG protein peaks were calculated and com-

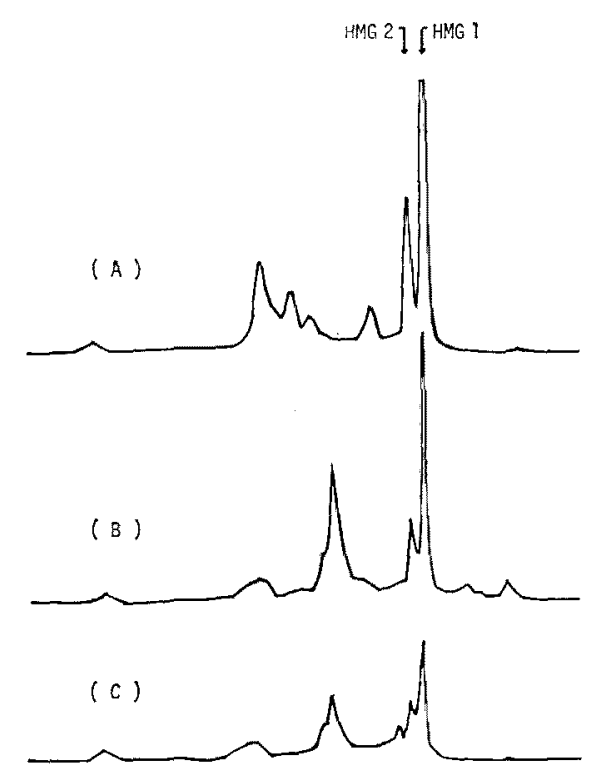

FiG. 5. Acid Gel Electrophoresis of High Mobility Group Proteins.

The high mobility group proteins were isolated from $0.75 \mathrm{mg}$ nuclei (A, calf thyms; $B$, lactation mammary glands; $C$, regression mammary glands) as described in Materials AND Methods. Aliquots of the high mobility group protein solution were applied to a slab gel with the buffer system of Johns. ${ }^{18)}$ pared between these two stages. Table I shows that the ratios of regression to lactation were about 0.3 and 0.7 for HMG-1 and HMG-2 protein, respectively.

To examine whether the apparent lower content of HMG proteins in the regression mammary glands were caused by degradation during the isolation procedure by some proteolytic enzymes which might be present in the tissue and might not be inhibited by phenylmethylsulfonyl fluoride, the complements of histones isolated from the same samples of nuclei as used for preparing HMG proteins were compared between the lactation and regression stages. For every component of histones, a higher content of in lactation nuclei was not observed. Although these results can not definitely exclude the possibility that a proteolytic enzyme which preferentially attacks the $H M G$ proteins, but not histones, is more active in the regression mammary gland than in the lactation tissue, it appears likely that the contents of the HMG proteins are lower in the regression mammary gland cells.

\section{DISCUSSION}

Chromatin is made up of a linear array of repeating subunits called nucleosome. ${ }^{10)}$ Each nucleosome consists of DNA and two molecules each of the histone $\mathrm{H} 2 \mathrm{~A}, \mathrm{H} 2 \mathrm{~B}, \mathrm{H} 3$ and H4. ${ }^{10)}$ Histone $\mathrm{Hl}$ is not part of the nucleosome, but is associated with it. In has been shown that the DNA repeat length of the nucleosome can very between 140 and 240 nucleotide pairs, depending on the organism and tissue from which the nucleosomes are 
isolated. ${ }^{21 \sim 23)}$ As a general correlation between DNA repeat length and transcriptional activity, Thomas and Thompson have pointed out that transcriptional cells have shorter nucleosome repeat lengths than less active cells. ${ }^{22)}$ Mammary gland chromatin template activity for in vitro transcription declines about two fold during the stage from early lactation to regression.9" The DNA repeat length of mammary gland chromatin, however, was essentially unvariable between these two stages (lactation, 195; regression, 198 nucleotide pairs). Variation in the DNA repeat length of mammary gland chromatin does not appear to be involved in the difference in the transcriptional activity of the mammary glands.

Post-translational histone modifications, e.g., phosphorylation, methylation or acetylation have been suggested as possible mechanisms for transcriptional regulation in chromatin. ${ }^{24}$ In particular, histone acetylation has been shown to be correlated with increased transcriptional activity. ${ }^{25 \sim 287}$ Electrophoretic patterns of histones isolated from mammary gland nuclei were compared between lactation and regression stages. The extent of acetylation of histone $\mathrm{H} 3$ and $\mathrm{H} 4$ was essentially unvariable between these two stages. Histone $\mathrm{H} 1$ isolated from regression mammary glands was more heterogeous than that from lactation tissue. This observation was consistent with the data represented by Stellwagen and Cole who showed by ion exchange chromatography that microheterogeneity of histone $\mathrm{Hl}$ changes during the development of the mammary glands. ${ }^{29}$ The higher order structure of chromatin such as the solenoid structure is generally believed to be dependent on histone H1 ${ }^{10)}$ Although the correlation between the higher order structure and transcriptional activity of chromatin remains unknown, modulations in the higher order structure might be involved in the transcriptional regulation in the mammary glands.

The HMG proteins which are a group of proteins loosely bound to chromatin consist of four proteins designated as HMG-1, HMG-2, HMG-14 and HMG-17. All four proteins from thymus have been purified to homogeneity and have been extensively investigated. There is a controversy as to whether the HMG proteins are specifically associated with transcriptionally active genes in chromatin. Vidali et $a l^{30)}$ and Levy et $a l^{31,32)}$ have shown that limited digestion of chromatin with nucleases, under conditions which have been shown to selectively hydrolyze active genes, causes the release of the HMG proteins. In contrast, Goodwin and Johns ${ }^{33)}$ have shown that in experiments of limited nuclease digestion of thymus and liver nuclei very little of the HMG proteins is released. Rabbani et $a l^{34)}$ have pointed out that the HMG proteins are present in a comparable amount with thymus in transcriptionally inactive chicken erythrocyte nuclei. The amounts of HMG-1 and HMG-2 protein per DNA were greater in lactation mammary gland than in regression tissue. No decline in each histone complement was observed between these two stages, suggesting that the decline in the HMG proteins is not caused by nonspecific proteolysis during isolation of these proteins. In our previous report, ${ }^{9}$ ) the mammary gland chromatin template activity of lactating rats has been shown to be more than twice that of regression stage of rats. Therefore, our results appear to support the argument that the HMG proteins are involved in active chromatin structure.

Recently, Gottesfeld et al. have devised a procedure to fractionate active and inactive chromatin. ${ }^{35,36)}$ To investigate the role of histone $\mathrm{H} 1$ modification and the $\mathrm{HMG}$ proteins on the transcriptional activity of mammary gland chromatin in more detail, it seems important to analyze these proteins in the active chromatin. This is now in progress.

Acknowledgment. This work was supported, in part, by a grant from The Agricultural Chemical Research Foundation. We thank Dr. T. Matoba (Kyoto University) for the help in densitometric tracings.

\section{REFERENCES}

1) M. R. Banerjee and D. N. Banerjee, Exptl. Cell Res., 64, 307 (1971). 
2) P. Chomczyński, W. Sokól-Misiak and D. Kleczkowska, FEBS Lett., 76, 191 (1977).

3) L. M. Houdebine, Eur. J. Biochem., 68, 219 (1976).

4) J. M. Rosen and S. W. Barker, Biochemistry, 15, 5272 (1976).

5) P. M. Terry, M. R. Banerjee and R. M. Lui, Proc. Natl. Acad. Sci. US., 74, 2441 (1977).

6) E. Devinoy, L. M. Houdebine and C. Delouis, Biochim. Biophys. Acta, 517, 360 (1978).

7) N. J. Nardacci, J. W. C. Lee and W. L. McGuire, Cancer Res., 38, 2694 (1978).

8) R. J. Matusik and J. M. Rosen, J. Biol. Chem., 253, 2343 (1978).

9) M. Hirose, M. Maki and H. Chiba, J. Biochem., 83, 1205 (1978).

10) G. Felsenfeld, Nature, 271, 115 (1978).

11) M. J. Tsai, R. J. Schwartz, S. Y. Tsai and B. W. O'Malley, J. Biol. Chem., 250, 5165 (1975).

12) K. Burton, Biochem. J., 62, 315 (1956).

13) M. Steinmetz, R. E. Streek and H. G. Zachau, Eur. J. Biochem., 83, 615 (1978).

14) A. C. Peacock and C. W. Dingman, Biochemistry, 6, 1818 (1967).

15) J. Bonner, G. R. Chalkley, M. Dahmus, D. Fambrough, F. Fujimura, R. C. Huang, J. Huberman, R. Jensen, K. Marushige, H. Chlenbusch, B. Olivera and J. Widholm, "Methods in Enzymology," Vol. XII (part B) ed. by L. Grossman and K. Moldave, Academic Press Inc., New York, N. Y., 1968 , p. 3.

16) S. Panyim and R. Chalkley, Arch. Biochem. Biophys., 130, 337 (1969).

17) J. M. Walker, G. H. Goodwin and E. W. Johns, FEBS Lett., 90, 327 (1978).

18) E. W. Johns, J. Chromato., 42, 152 (1969).

19) E.W.Wilson and T.C. Spelsberg, "Methods in Enzymology," Vol. XL (part E), ed. by B.W.
O'Malley, Academic Press Inc., New York, N. Y., 1975, p. 171.

20) U. K. Laemmli, Nature, 227, 680 (1970).

21) N. R. Morris, Cell, 8, 357 (1976).

22) J. O. Thomas and R. J. Thompson, Cell, 10, 637 (1977).

23) J. L. Compton, M. Bellard and P. Chambon, Proc. Natl. Acad. Sci. US., 73, 4382 (1976).

24) V. G. Allfrey, "Chromatin and Chromosome Structure," ed. by H. J. Li and R. A. Eckhardt, Academic Press Inc., New York, N. Y., 1977, p. 167.

25) K. Marushige, Proc. Natl. Acad. Sci. US., 73, 3937 (1976).

26) C.K. Shewmaker, B.W. Cohen and T.E. Wagner, Biochem. Biophys. Res. Comm., 84, 342 (1978).

27) D. A. Nelson, M. Perry, L. Sealy and R. Chalkley, Biochem. Biophys. Res. Comm., 82, 1346 (1978).

28) J. R. Davie and E. P. M. Candido, Proc. Natl. Acad. Sci. US., 75, 3574 (1978).

29) R. H. Stellwagen and R. D. Cole, J. Biol. Chem., 243, 4456 (1968).

30) G. Vidali, L. C. Boffa and V. G. Allfrey, Cell, 12, 409 (1977).

31) B. Levy, N. C. W. Wong and G. H. Dixon, Proc. Natl. Acad. Sci. US., 74, 2810 (1977).

32) B. Levy, W. Connor and G. H. Dixon, J. Biol. Chem., 254, 609 (1979).

33) G. H. Goodwin and E. W. Johns, Biochim. Biophys. Acta, $\mathbf{5 1 9}$ (1978).

34) A. Rabbani, G. H. Goodwin and E.W. Johns, Biochem. Biophys. Res. Comm., 81, 351 (1978).

35) J. M. Gottesfeld, R. F. Murphy and J. Bonner, Proc. Natl. Acad. Sci. US., 72, 4404 (1975).

36) J. M. Gottesfeld and R. J. G. Butler, Nuc. Acid. Res., 4, 3155 (1977). 